\title{
SENGKETA DALAM PERKAWINAN KEDUA TANPA IZIN ISTRI PERTAMA
}

\author{
I Gede Agus Dedy Andika, I Nyoman Gede Sugiartha, Ni Made Puspasutari Ujianti \\ Fakultas Hukum, Universitas Warmadewa, Denpasar-Bali, Indonesia \\ agusdedeandika@icloud.com, nyomansugiarta14@gmail.com, puspasutarinjianti@gmail.com
}

\begin{abstract}
Abs trak
Perkawinan menurut Undang-Undang Nomor 1 Tahun 1974 tentang Perkawinan adalah ikatan lahir batin antara seorang laki-laki dengan seorang perempuan untuk membentuk rumah tangga yang bahagia. Kewenangan poligami tidak mutlak di tangan suami, tapi ada syarat lain yang harus dipenuhi yaitu mendapatkan izin dari hakim (pengadilan). Tujuan penelitian ini untuk menganalisa pengaturan sanksi pidana dalam perkawinan kedua tanpa izin istri pertama serta akibat hukum terhadap perkawinan kedua yang tidak memenuhi ketentuan hukum yang berlaku. Penelitian ini menggunakan metode penelitian hukum normatif dengan pendekatan Perundangundangan. Sumber bahan hukum yang digunakan yaitu sumber bahan hukum primer dan sekunder. Teknik pengumpulan data dilakukan dengan cara meneliti bahan pustaka yang ada yang kemudian dianalisis secara sistematis. Hasil penelitian mengungkapkan bahwa bahwa Sanksi pidana yang diberikan dalam perkawinan kedua kalinya tanpa memberikan keterangan yang tidak benar berdasarkan ketentuan pidana dalam PP Nomor 9 Tahun 1975 yang merupakan lex specialis terhadap KUHPidana. Akibat hukum terhadap perkawinan yang kedua yaitu bila suami sudah menikah lagi atau berpoligami tanpa sepengetahuan dari istri pertama, maka istri pertama dapat menuntut dengan mengajukan permohonan pembatalan pernikahan yang terdapat didalam pasal 22-29 Undang-Undang Perkawinan.
\end{abstract}

Kata Kunci: Izin Istri Pertama, Perkawinan, Sengketa

\begin{abstract}
Marriage according to Law Number 1 of 1974 concerning Marriage is an inner and outer bond between a man and a woman to form a happy household. The authority of polygamy is not absolute in the hands of the husband, but there are other conditions that must be met, namely obtaining permission from the judge (court). The purposes of this study are to analyze the regulation of criminal sanctions in a second marriage without the permission of the first wife and the legal consequences of a second marriage that does not meet the applicable legal provisions. This study uses a normative legal research method with a statutory approach. Sources of leg al materials used are primary and secondary sources oflegal materials. Data collection techniques were carried out by examining existing library materials which were then analyzed systematically. The results of the study reveal that criminal sanctions are given in the second marriage without providing incorrect information based on the criminal provisions in PP No. 9 of 1975 which is a lex specialis of the Criminal Code. The legal consequence of the second marriage is that if the husband has remarried or is polygamous without the knowledge of the first wife, the first wife can sue by submitting a request for annulment of the marriage contained in Articles 22-29 of the Marriage Law.
\end{abstract}

Keywords: First Wife Permission, Marriage, Dispute

\section{PENDAHULUAN}

Perkawinan menurut Undang-Undang Nomor 1 Tahun 1974 Tentang Perkawinan adalah ikatan lahir batin antara seorang laki-laki dengan seorang perempuan untuk membentuk rumah tangga yang bahagia yang kekal berdasarkan ketentuan Yang Maha Esa. Esensi dari pasal tersebut bahwa tujuan dari perkawinan membentuk dari sebuah keluarga yang bahagia dan kekal berdasarkan kekuatan Yang Maha Esa atau berdasarkan Hukum Agama (Setiono \& Bahroni, 2018).

Berdasarkan hukum positif yang berlaku, perkawinan pada dasarnya menganut asas monogami. Asas ini hanya memberikan peluang seorang pria mempunyai seorang istri, dan begitu juga sebaliknya. Hal itu telah diatur secara limitatif. Suatu kehidupan rumah tangga, untuk terciptanya suatu keluarga yang tentram dan Bahagia harus ada keseimbangan tugas antara suami, istri dan anakanak. Ketentraman hidup dalam rumah tangga menjadi suatu cita-cita yang harus dicapai dalam kehidupan berkeluarga. Untuk terciptanya suatu ketentraman dalam rumah tangga maka harus ada 
rasa kasih sayang, rasa kebersamaan, kesenangan dan saling percaya. Namun tidak semua perkawinan akan berjalan dengan lancar dan tanpa hambatan. Permasalahan dapat muncul dalam perjalanan dalam suatu rumah tangga. Ketika dalam suatu kehidupan perkawinan itu diisi dengan banyak kebohongan dan tidak adanya rasa kebersamaan, kasih sayang dan saling menghargai maka akan terciptalah suatu pertengkaran yang bisa mengakibatkan retaknya suatu rumah tangga, baik itu pertengkaran, perceraian dan bahkan poligami (Soimin, 2010).

Persetujuan istri sering kali menjadi persoalan inti dalam poligami, dimana seorang suami melakukan perkawinan untuk kedua kalinya atau lebih tanpa izin dari istri yang pertama (terdahulu). Perkawinan ini biasanya dilakukan di bawah tangan atau yang lazim disebut "nikah-siri". Dasarnya, pasal 56 telah menjelaskan bahwa seseorang yang hendak beristri lebih dari seorang harus mendapat izin dari pengadilan dan permohonan izin tersebut dilakukan menurut tata cara sebagaimana diatur dalam bab VIII PP No. 9 Tahun 1975 (Arifah et al., 2016). Lebih lanjut, jika dilihat berbagai hukum positif di Indonesia yang mengatur tentang poligami ilegal, maka dapatlah diketahui bahwa perbuatan poligami illegal dipandang sebagai perbuatan pidana, akan tetapi sanksi pidana yang mengancam perbuatan poligami ilegal dapat berbeda-beda tergantung dari peraturan mana memandangnya. Jika dipandang dari Pasal 45 kepada Peraturan Pemerintah Nomor 9 Tahun 1975, maka dilihat bahwa perbuatan poligami illegal hanyalah sebagai wetsdeliktern (pelanggaran administratif) semata yang ancaman sanksinya denda setinggi-tinggi Rp. 7.500.- (tujuh ribu lima ratus rupiah). Tindak pidana menikah lagi tanpa izin dari isteri sebelumnya pada dasarnya termasuk kepada tindak pidana pelanggaran terhadap kedudukan perdata. Ada 4 (empat) Pasal yang berhubungan dengan tindak pidana pelanggaran kedudukan perdata ini, yaitu sebagaimana diatur dalam Pasal 277, 278, 279 dan Pasal 180 KUHP (Sekoh, C.E.). Sedangkan jika dilihat dari sudut pandang Pasal 279 Kitab Undangundang Hukum Pidana maka perbuatan poligami ilegal akan terpandang sebagai rechtsdeliktern (perbuatan pidana kejahatan kategori ringan) dengan ancaman penjara maksimal 5 (lima) tahun, namun jika perbuatan tersebut didasari atas kebohongan maka ancaman pidana maksimal 7 (tujuh) tahun penjara (Subekti, 1980).

Adapun penelitian sebelumnya mengungkapkan bahwa praktik poligami yang dilakukan oleh suami tanpa adanya izin dari isteri pertama merupakan kobohongan dan pengkhinatan suami terhadap isteri, dan dapat dikategorikan sebagai bentuk kekerasan rumah tangga dalam konteks kekerasan secara psikis (Rizkal, 2019). Ditinjau dari hukum positif menganggap perkawinan tanpa adanya izin dari istri pada perkawinan terdahulunya yang sah sebagai suatu perzinahan karena perkawinan tersebut meskipun sah menurut hukum agama, tetapi tidak diakui oleh Negara (Rochxy \& Lesmana, 2013). Sanksi pidana terhadap pihak-pihak yang melangsungkan perkawinan poligami tanpa adanya penetapan pengadilan yaitu ancaman hukuman pidana lima sampai tujuh tahun terhadap laki-laki yang melangsungkan perkawinan (Siregar, 2017). Dari fenomena tersebut maka dilakukannya penelitian yang bertujuan untuk menganalisa pengaturan sanksi pidana dalam perkawinan kedua tanpa izin istri pertama serta akibat hukum terhadap perkawinan kedua yang tidak memenuhi ketentuan hukum yang berlaku.

\section{METODE PENELITIAN}

Dalam mengungkap permasalahan yang terjadi, peneliti menggunakan tipe penelitian hukum normatif yang dipergunakan di dalam penelitian hukum yang dilakukan dengan cara meneliti bahan pustaka yang ada dengan mengaplikasikan pendekatan perundang-undangan dengan mengkaji peraturan perundang-undangan dan peraturan pelaksanaan terkait khususnya yang bersangkut paut dengan permasalahan mengenai sengketa dalam perkawinan kedua tanpa izin dari istri pertama. Teknik pengumpulan data dilakukan dengan cara meneliti bahan pustaka yang ada Sumber bahan hukum yang digunakan adalah bahan hukum primer yang didapat dengan menganalisis peraturan perundangundangan, risalah resmi, dan beberapa keputusan-keputusan yang menyangkut dengan judul penelitian ini. Bahan hukum sekunder didapat dari menganalisis buku-buku, jurnal-jumal dan hasilhasil penelitian terdahulu yang kemudian dianalisis secara sistematis.

\section{HASIL DAN PEMBAHASAN}

\section{Pengaturan Sanksi Pidana dalam Perkawinan Kedua Tanpa Izin Istri Pertama}

UU No. 1 Tahun 1974 tentang Perkawinan tidak dapat dipisahkan dengan Kitab Undang-Undang Hukum Pidana (KUH Pidana) dengan dua alasan, yaitu pertama, berdasarkan asas lex specialis 
derogate lex generalis, dalam hal ini, ketentuan pidana dalam UU No. 1 Tahun 1974 jo. PP No. 9 Tahun 1975 merupakan ketentuan khusus dari KUH Pidana. Kedua, berdasarkan bahwa Hukum Tata Pemerintahan dan Hukum Pidana saling melengkapi, hukum pidana dijadikan sarana untuk bisa menjalankan hukum tata pemerintahan. Dalam hal ini UU No. 1 Tahun 1974 merupakan salah satu sumber hukum tata pemerintahan, sedangkan KUH Pidana merupakan salah satu sumber hukum pidana di Indonesia. Oleh karena itu, maka untuk mempertahankan UU No. 1 Tahun 1974 agar ditaati, ia perlu didukung oleh KUH Pidana. Berdasarkan redaksi Pasal 145 Draft RUU HMPA dapatlah diketahui bahwa perbuatan poligami sama sekali tidak dilarang selama suami yang ingin berpoligami mendapatkan izin dari pengadilan. Perbuatan poligami yang dilakukan secara ilegal (tanpa izin pengadilan) dapat dikenakan sanksi pidana berupa delik pidana pelanggaran dengan sanksi yang sedikit lebih tinggi dari ketentuan Pasal 45 PP Nomor 9 Tahun 1975 yaitu membayar denda paling banyak Rp. 6.000.000,- (enam juta rupiah) atau hukuman paling lama 6 (enam) bulan (Bahari, 2012).

Ketentuan pidana dalam PP Nomor 9 Tahun 1975 merupakan lex specialis terhadap KUH Pidana, apabila ternyata seorang Petugas pencatat pernikahan (PPN) melanggar ketentuan Pasal 44 PP Nomor 9 Tahun 1975, yaitu mengawinkan suami yang belum memperoleh izin poligami dari pengadilan, maka terhadapnya hanya diancam pidana berupa kurungan selama-lamanya 3 bulan atau denda setinggi- tingginya Rp. 7.500,- (Pasal 45 ayat (1) huruf b PP Nomor 9 Tahun 1975), terhadapnya tidak dapat diancam pidana berupa penjara selama-lamanya dua tahun delapan bulan atau denda sebanyak-banyaknya Rp. 4.500,- sebagaimana tersebut dalam Pasal 436 ayat (2) KUH Pidana, karena materi yang diatur dalam Pasal 45 ayat (1) huruf b PP Nomor 9 Tahun 1975 sama dengan materi yang diatur dalam Pasal 436 (2) KUH Pidana, oleh karena itu, ketentuan yang terakhir harus dikesampingkan berdasar asas lex specialis derogate lex generalis. Lain halnya, jika seorang suami yang kawin lagi tanpa izin pengadilan, maka terhadapnya harus diterapkan ketentuan pidana dalam Pasal 279 ayat (1) ke 1 KUHP, yaitu ancaman pidana selama lima tahun, terhadapnya tidak dapat diancam pidana menurut ketentuan Pasal 45 ayat (1) PP Nomor 9 Tahun 1975, karena yang diatur secara khusus dalam PP tersebut adalah pelanggaran ketentuan administrasi perkawinan, tidak mengatur secara khusus mengenai ancaman pidana bagi suami yang kawin lain padahal perkawinannya yang sudah ada menjadi halangan sah baginya untuk kawin (Muhammad, 1990).

Berdasarkan uraian di atas, dapat disimpulkan bahwa bagi orang yang melakukan poligami tanpa izin pengadilan diancam dengan sanksi:

1. Sanksi perdata berupa ancaman pembatalan perkawinan

2. Sanksi pidana berupa:

a. Denda setinggi-tingginya Rp.7.500,-(tujuh ribu lima ratus rupiah) karena pelanggaran administrasi perkawinan (Pasal 45 ayat (1) huruf a PP No. 9 Tahun 1975).

b. Penjara selama-lamanya lima tahun karena kawin, sedang ia mengetahui, bahwa perkawinannya yang sudah ada menjadi halangan baginya akan kawin lagi (Pasal 279 ayat (1) ke 1 KUH Pidana). Hal ini berlaku juga bagi pihak isteri kedua bila ia mengetahui suaminya itu sudah kawin.

c. Penjara selama-lamanya 7 tahun karena menyembunyikan kepada pihak lain bahwa dirinya telah kawin sehingga perkawinannya itu menjadi halangan untuk kawin lagi (Pasal 279 ayat (2) ke 2 KUH Pidana).

d. Penjara selama-lamanya 5 tahun karena menyembunyikan kepada pihak lain bahwa ada halangan baginya untuk kawin (Pasal280 KUH Pidana).

Bagi PPN yang mengawinkan suami yang berpoligami tanpa izin pengadilan dikenakan sanksi pidana berupa kurungan selama-lamanya tiga bulan atau denda setinggi-tingginya Rp. 7.500,(tujuh ribu lima ratus rupiah). Delik sebagaimana diuraikan di atas merupakan pelanggaran dan termasuk delik aduan, oleh karena itu penegakannya ditentukan sikap proaktifnya pihak isteri yang dimadu. Setiap orang yang melakukan perkawinan poligami tanpa melalui prosedur yang telah ditetapkan oleh Undang-undang dapat dituntut menurut Pasal 279 KUHPidana. Meskipun demikian perkawinan poligami tidak sesuai dengan aturan Undang-undang atau disebut juga poligami liar yang terjadi di tengah-tengah kehidupan masyarakat yang tidak tersentuh oleh hukum namun ada juga tindak pidana perkawinan itu dituntut berdasarkan Pasal279 KUHPidana tersebut.

Ketika perkawinan menjadi tindak pidana, maka ada beberapa orang yang menjadi pelaku perbuatan tersebut, yaitu suami (laki-laki) dan istri (perempuan). Berdasarkan Pasal 279 KUH Pidana hukuman itu dijatuhkan kepada kedua pelaku tersebut, namun pada pelaksanaannya banyak kasus 
tindak pidana perkawinan (poligami tanpa izin istri dan pengadilan) yang pidananya hanya dijatuhkan kepada pelaku laki-laki saja (suami), sedangkan perempuan (istri kedua) tidak semua perempuan yang melakukan tindak pidana didakwa melakukan perbuatan yang sama.

\section{Akibat Hukum Terhadap Perkawinan Kedua yang Tidak Memenuhi Ketentuan Hukum yang Berlaku}

Ketika sang suami melakukan poligami tanpa memenuhi persyaratan yang telah ditentukan dalam Undang-undang perkawinan seperti izin dari sang istri,maka sang istri dapat melakukan permohonan pembatalan perkawinan. Bila suami sudah menikahi lagi atau berpoligami tanpa sepengetahuan dari istri pertama, maka istri pertama dapat menuntut dengan mengajukan permohonan pembatalan pernikahan yang terdapat didalam pasal 22-29 Undang-Undang Perkawinan. Pembatalan perkawinan hanya dapat dilakukan dengan putusan pengadilan, sehingga dengan adanya putusan pengadilan sebuah perkawinan yang sudah terjadi dianggap tidak pernah ada. Namun meskipun perkawinan itu sudah dianggap tidak pernah ada, tidak serta merta menghilangkan akibat hukum dalam perkawinan yang pernah dilakukan.

Pembatalan perkawinan tentu dapat dipastikan masuk dalam area hukum acara atau hukum formal sehingga lahir suatu putusan pengadilan. Karena putusan pengadilan ini merupakan peristiwa hukum akibat dari perbuatan hukum terhadap suatu perkawinan orang lain, bukan putusan terjadinya perceraian. Perbuatan hukum yang dimaksud ini merupakan pengajuan permohonan pembatalan perkawinan yang diajukan oleh pihak yang mempunyai hak sebagaimana ditentukan dalam Pasal 23 Undang-undang perkawinan ditegaskan bahwa yang dapat mengajukan pembatalan perkawinan yaitu:

a. Para keluarga dalam garis keturunan lurus keatas dari suami dan isteri.

b. Suami isteri.

c. Pejabat yang berwenang hanya selama perkawinan belum diputuskan.

d. Pejabat yang ditunjuk tersebut ayat (2) pasal 16 Undang-Undang ini dan setiap orang yang mempunyai kepentingan hukum secara langsung terhadap perkawinan tersebut, tetapi hanya setelah perkawinan itu putus.

Pembatalan perkawinan hanya dapat dilakukan bila terjadi pelanggaran sebagaimana ditentukan dalam Undang-undang perkawinan. Sebagai suatu ikatan, perkawinan merupakan bagian dari hukum perdata (hukum privat). Karena perkawinan berlangsung dari suatu kesepakatan para pihak pria dan wanita yang dalam hal ini didasarkan pada rasa cinta dan kasih sayang serta kesepakatan untuk membentuk keluarga yang bahagia dan kekal. Adapun konsekuensi dari pelanggaran perkawinan siri tanpa izin istri pertama dalam hukum perdata yaitu hak atas harta gono gini, bila keadaanya seorang laki-laki yang sudah berkeluarga lalu memiliki istri muda yang dinikahi secara siri, maka bila istri muda tersebut melahirkan anak maka anaknya menurut hukum Negara disebut sebagai anak zina, yang efeknya adalah anak itu tidak bisa menjadi ahli waris dari bapak biologisnya namun memiliki hak untuk dinafkahi.

Apabila terjadi perceraian maka istri siri secara hukum tidak berhak untuk menuntut hak pembagian harta gono-gini, karena pernikahan siri itu dianggap tidak pernah ada dan tidak pernah terjadi. Selain tidak mendapatkannya hak atas harta pernikahan siri juga tidak dapat membuat akta perkawinan yang ke dua. Perkawinan kedua kali tanpa izin istri pertama atau yang biasa disebut kawin siri, jelas sudah melanggar hukum, karena tidak dapatnya menunjukkan bukti sah telah terjadinya atau berlangsungnya perkawinan, tidak adanya bukti inilah yang menimbulkan konsekuensi anak dan istri dari perkawinan siri tidak memiliki status hukum legalitas di hadapan Negara. Berdasarkan pasal 2 ayat (2) undang-undang perkawinan mempunyai kewajiban mencatatkan perkawinanya ke Kantor Urusan Agama (KUA) dan mendapatkan buku nikah sebagai bukti pencatatan perkawinan. Bahwa sepanjang belum ada kata talak kepada istri, tentunya istri masi merupakan istri sah dari suami. Namun demikian perkawinan juga merupakan bagian dari hukum pidana (Hukum publik) yang apabila dalam prosesnya memenuhi unsur-unsur materli sebagai tindakan kejahatan dan pelanggaran. Dimana setiap kejahatan dan pelanggaran dapat diancam pidana bagi setiap pelakunya.

Kemudian dalam pasal 279 KUHP ayat (1) mengatur bahwa kejahatan terhadap perkawinan adalah bagi siapa saja yang mengadakan perkawinan yang telah ada menjadi penghalang untuk sahnya perkawinan tersebut dalam pasal ini mengatur bahwa perkawinan yang dilakukan oleh 
seorang pria padahal masih terikat dengan perkawinan dengan wanita lain dan perkawinan tersebut dilakukan dengan cara yang bertentangan dengan ketentuan hukum perkawinan (melebihi dari empat orang istri) maka perkawinan tersebut merupakan suatu perbuatan pidana yang diancam dengan pidana paling lama lima tahun. Dalam pasal ini menjelaskan perkawinan yang dilangsungkan tidak dihadapan petugas pencatat perkawinan dikategorikan sebagai pelanggaran, atau perbuatan menyimpang dari norma-norma hukum yang berlaku, hal ini juga diatur dalam undang- undang perkawian, bahwa perkawinan harus dicatatkan menurut undang-undang yang berlaku dan dalam komplikasi hukum islam pasal 6 ayat (2). Proses pembatalan perkawinan sama dengan tata cara gugatan perceraian, baik itu pemanggilan, pemeriksaan dan putusan pembatalan pernikahan perkawinan poligami, sebagaimana yang diatur dalam pasal 20 sampai 306 PP No. 9 Tahun 1975. Pembatalan perkawinan yang di lakukan oleh istri terhadap suami yang menikah lagi tanpa izin istri, tidak ada batas waktunya dalam melakukan proses pembatalan perkawinan dan kapanpun istri dapat mengajukan permohonan pembatalan perkawinan.

\section{SIMPULAN DAN SARAN}

\section{Simpulan}

Sanksi pidana yang diberikan dalam perkawinan kedua kalinya tanpa memberikan keterangan yang tidak benar berdasarkan ketentuan pidana dalam PP Nomor 9 Tahun 1975 merupakan lex specialis terhadap KUH Pidana, apabila ternyata seorang Petugas pencatat pernikahan (PPN) melanggar ketentuan Pasal 44 PP Nomor 9 Tahun 1975, yaitu mengawinkan suami yang belum memperoleh izin poligami dari pengadilan, maka terhadapnya hanya diancam pidana berupa kurungan selama-lamanya 3 bulan atau denda setinggi- tingginya Rp. 7.500,-. Berdasarkan Pasal 279 KUH Pidana yang berbunyi "barang siapa mengadakan perkawinan padahal mengetahui bahwa perkawinan atau perkawinan-perkawinannya yang telah ada menjadi penghalang yang sah untuk itu. Barang siapa mengadakan perkawinan padahal mengetahui bahwa perkawinan atau perkawinan-perkawinan pihak lain menjadi penghalang untuk itu, maka diancam dengan pidana penjara paling lama lima tahun". Adapun akibat hukum terhadap perkawinan yang kedua yaitu bila suami sudah menikah lagi atau berpoligami tanpa sepengetahuan dari istri pertama, maka istri pertama dapat menuntut dengan mengajukan permohonan pembatalan pernikahan dalam ketentuan pasal 279 KUHP juncto pasal 2229 Undang- Undang Perkawinan tentang pembatalan perkawinan.

\section{Saran}

Diharapkan kepada pemerintah tentunya Indonesia dapat memberikan pembaharuan hukum dan pertimbangan hukum dalam perkawinan yang menyimpang terutama mengenai sanksi poligami di Indonesia yang sangat kecil. Diharapkan para pembuat hukum atau aturan bisa mengevaluasi aturan perkawinan yang menyimpang yang terjadi di Indonesia yang mengakibatkan perselisihan diantara kedua belah pihak. Bagi suami yang ingin melakukan poligami hendaklah memikirkannya terlebih dahulu, karena secara umum poligami itu lebih banyak menimbulkan dampak yang tidak baik terhadap keharmonisan keluarga. Selain itu poligami juga mengakibatkan terabainya hak-hak isteri dan anak-anak.

\section{DAFTAR PUSTAKA}

Arifah, A. N., Sholehah, R., \& Hardianto, T. (2016). Poligami Kiai: Praktek Poligami Kiai di Kota Jember dalam Pandangan Khi dan Gender. Yudisia, 7(1), 120-145.

Bahari, A. (2012). Prosedur Gugatan Cerai, Pembagian Harta Gono-Gini, Hak Asuh Anak. Pustaka Yustisia, Yogyakarta.

Muhammad, A. (1990). Hukum Perdata Indonesia. Citra Aditya Bakti, Bandung.

Rizkal. (2019). Poligami Tanpa Izin Isteri dalam Perspektif Hukum: Bentuk Kekerasan Psikis Terhadap Isteri. Jurnal Yustisia, 22(1), 26-36.

Rochxy, \& Lesmana, B. (2013). Pemidanaan Terhadap Pelaku Perkawinan di Bawah Tangan Tanpa Izin Istri Pertama. Jurnal Yudisial, 6(3), 250-266.

Sekoh, C. H. (21 C.E.). Kajian Yuridis Terhadap Suami Menikah Kembali (Poligami) Tanpa Izin Istri Pertama ditinjau dari Undang-undang Nomor. 1 Tahun 1974 Tentang Perkawinan. Lex Privatum2, 9(2), 129-139.

Setiono, G. C., \& Bahroni, A. (2018). Tinjauan Yuridis Tentang Poligami Tanpa Izin Isteri Menurut 
Kompilasi Hukum Islam (KHI). Dinamika Hukum \& Masyarakat, 1(1), 1-25.

Siregar, M. Y. (2017). Sanksi Pidana Terhadap Perkawinan Poligami Tanpa Adanya Persetujuan Istri. Jurnal Ilmiah Advokasi, 5(1), 52-73.

Soimin, S. (2010). Hukum Orang dan Keluarga: Perspektif Hukum perdata Barat/BW, Hukum Islam, dan Hukum Adat. Sinar Grafika, Jakarta.

Subekti. (1980). Pokok-Pokok Hukum Perdata. Intermasa, Jakarta. 